\title{
One Hundred Years of Philosophy of Science: The VIEW From Munich
}

Carlos Ulises Moulines, 2008, Die Entwicklung der modernen Wissenschaftstheorie (1890-2000): Eine historische Einführung, Lit Verlag, Hamburg, 210 pp.

These days, a number of philosophers of science indulge in lamenting about a crisis of their discipline. They complain about its loss of relevance, and bemoan the marginalization of their discipline in the philosophical community and in the wider academia (cf. Howard (2003, 75), Hardcastle and Richardson (2003)). The Munich take on the philosophy of science does not succumb to this temptation. According to it, philosophy of science is well and alive. In Carlos Ulises Moulines's Die Entwicklung der modernen Wissenschaftstheorie (1890-2000) Eine historische Einführung (henceforth Einführung) the word "crisis" is used only in reference to the 1940s when classical logical positivism encountered some difficulties in dealing with problems concerning verification, the analytic/synthetic distinction, and similar conundrums. For Moulines, "crisis" is not a word that applies to contemporary philosophy of science. My expectations to find an encouraging piece of philosophy of science, something one doesn't come across so often today, grew, when I hit upon a Mexican review of the French version of Einführung that concluded with the enthusiastic verdict that "the community of philosophers of science may congratulate themselves for the publication of this book" (Crítica 38 (2006), 120). Not only the French but also the German version of Moulines's book has found an extremally positive reception in certain quarters. A recent review of Einführung closes with the following acolades: "Without overstatement we claim that [Einführung] is the best historical overview of modern philosophy of science that has been published in German", and, the enthusiastic Austrian reviewers felt obliged to add, "[it is] the one and only existing book of this kind" (Journal of General Philosophy of Science (2010), DOI 10.1007/s10838-010-9133-x). So it seems well worth our time to take a closer look at Moulines's achievements.

The view from Munich is not just any view. On a map of contemporary philosophy Munich is, if one happens to consult a German atlas, the home of the Münchner Schule, founded by the Austro-German philosopher Wolfgang Stegmüller some forty years ago (cf. Stadler 2010). In 1993 Carlos Ulises Moulines followed Stegmüller on the chair of philosophy, logic, and philosophy of science at the University of Munich. Together with Wolfgang Balzer he is a leading figure of the so-called structuralist philosophy of science founded by Joseph Sneed and 
Stegmüller in the 1970s, building on the work of Patrick Suppes in the 1950s. Thus, someone interested in the German scene of philosophy of science should take notice of how one of the protagonists of the Münchner Schule describes the evolution and the present state of his discipline at the beginning of a new century. ${ }^{1}$

A French version of Einführung was published in 2006 under the title La philosophie des sciences. L'invention d'une discipline. This title more clearly expresses the basic intention of the book than the blander German terms "Entwicklung" and "Einführung". The French and the German version are not identical. Some extra pieces have been added to the German version. The most significant changes are an expanded preface, and two new sections on more recent developments in philosophy of science, among them a half-section on the "New Experimentalism" of Ian Hacking (175ff.) and a section on the "Structural Realism“ of John Worrall (188ff).

Einführung is not only intended to be an historical introduction to philosophy of science, it is also supposed to be a work of history of philosophy of science that presents a substantial thesis on how this discipline developed and how the results of this development are to be assessed. Due to its panoramic character the book deals with a variety of different issues related in one sense or other to philosophy of science. I do not intend to discuss them all in this review. Instead, I'll concentrate on a few that may be particularly interesting for assessing Einführung.

As Moulines rightly remarks, Einführung does not offer novelties to the expert in matters of history of philosophy of science, rather it seeks to give an overall account of the evolution of the discipline during the last century. According to the author, this has been a desideratum until now, since, according to his knowledge, Einführung is the first panoramic survey of this kind in any language (ibid., 7):

Seit ihrer Geburtsstunde in den 80er Jahren des 19. Jahrhunderts hat unsere Disziplin (die Wissenschaftstheorie, T.M.) eine ... Entwicklung erfahren, die ... als globaler Prozess noch sehr ungenügend erforscht worden ist.

In den letzten Jahren habe ich mich verstärkt der ideengeschichtlichen Problematik meines eigenen Fachs gewidmet, in der Hoffnung einen Beitrag zur Schließung dieser historiographischen Lücke zu leisten. Ein erstes Ergebnis dieser Bemühungen ist ... La Philosophie des sciences. L'invention d'une discipline. (Die Entstehung der Wissenschaftstheorie als interdisziplinäres Fach, 3). ${ }^{2}$

1 Since up to now there is no English translation of Einführung I think it is appropriate to give the quotes in German. This may enable the reader to get a feeling of the original that otherwise may be lost.

2 Die Entstehung der Wissenschaftstheorie als interdisziplinäres Fach is a lecture that was given at a meeting of the Bavarian Academy of Sciences. It is essentially a version of the first chapter of Einführung. This evidences that the author considers Einführung not merely as an introductory text but also as a serious contribution to the history of philosophy of science. 
The basic thesis of Einführung is that the evolution of philosophy of science follows a "dialectical" pattern of different phases such that the structuralist theory of science, favored by the author, is to be considered as a kind of dialectical synthesis of earlier phases; in particular, structuralism is the only existing account of philosophy of science that does justice to the historicist (diachronic) and structural (synchronic) aspects of scientific knowledge. This is non-trivial and probably controversial thesis, but not quite new-already Stegmüller in A Combined Approach to the Dynamics of Theories. How to Improve Historical Interpretations of Theory Change by Applying Set Theoretical Structures (Stegmüller 1979) had put forward a similar claim:

I even dare to predict that at present his ideas (i.e. Sneed's, T.M.) form the best foundation in order to bridge the systematically oriented and the historically oriented philosophy of science. (Stegmüller 1979, 152)

It is my hope that some of the logical reconstruction sketches given in this paper will contribute to a better understanding of the dynamic aspects of theories and to the erection of a stable bridge between the systematically and the historically (as well as psychologically) oriented philosophy of science. (ibid. 181)

Indeed, as we shall see, Einführung remains faithful to the spirit and the style of the founder of the Münchner Schule. This holds also for the blind spots to be found in both accounts.

In chapter I the author sketches the different phases of the evolution of philosophy of science that in the subsequent chapters II - VI are treated in greater detail. From its beginnings in the last decades of the 19th century to the end of 20th century he distinguishes five "phases" in the development of philosophy of science:

II. Preformation (1890-1918)

III. Unfolding (1918-1935)

IV. Crisis and Consolidation (1935-1970)

V. Historicism (1960-1985)

VI. The Model-theoretic Account (1985-2000)

Moulines's "phases” are not just historical periods. Rather, phases are characterized by the specific aspect of science that they emphasize at the expense of others. For instance, the preformative phase is characterized by emphasizing the historical evolution of scientific knowledge, while it has not much to say about the logical structure of scientific knowledge. In contrast, the subsequent phase of unfolding, which historically may be roughly identified with the heyday of the Logical Empiricism of the Vienna Circle, is said to have laid more emphasis on the investigation of the logical structure of theories while ignoring the historical development. Indeed, the author contends, there is a sort of dialectics between subsequent phases. The ultimate phase of the model-theoretic account is distinguished from 
the earlier ones through the fact that here at last a kind of synthesis is reached in which the achievements of the earlier phases are "sublated" (aufgehoben) in a Hegelian sense. This is, of course, the merit of the structuralism of the Münchner Schule.

The history of philosophy of science is not a virgin field (cf. Uebel 2010). On the contrary. In the last decades, perhaps due to a certain stagnation of philosophy of science proper, a plethora of articles, monographs, and anthologies has been published on a wide variety of issues dealing with the history of philosophy of science. One may contend that today we understand the past of the philosophy of science better than ever before. This holds in particular for Logical Empiricism and Neokantianism whose contributions to the evolution of the discipline have been seriously misunderstood or were simply ignored in the past. For readers of the Yearbook it is hardly necessary to give a complete list of authors who contributed to this development. But for the sake of clarity, let us mention authors such as Coffa, Creath, Ferrari, Friedman, Haller, Reisch, Ryckman, Stadler, Uebel, to name but a few. Einführung does not mention one of them.

In the preface of Einführung Moulines offers a kind of explanation of this remarkable fact. According to him, Einführung does not intend to compete with "Einzelstudien" primarily written for professional philosophers. Rather, Einführung has been written with non-specialized readers in mind who "might have heard that there is a discipline named 'Wissenschaftstheorie' and wish to learn something about its general development (8)". ${ }^{3}$ In other words, he contends that the "Einzelstudien" do not contribute anything to our understanding of the global development of philosophy of science. This is a highly questionable thesis. I think that the distinction between "Einzelstudien" concerned with historical details and technicalities on the one hand, and general treatises that deal with the global picture and the broad lines of the evolution does not hold water. Rather, many of the works that have to be characterized as "Einzelstudien" brought about profound revisions of the conventional wisdom and the traditional pictures that dominated the discourse of history of philosophy for decades. This holds, as we shall see, for the received view of standard Logical Empiricism, but also for the role of Kant and Kantian philosophy for 20th century philosophy of science, and many other issues. In other words, by leaving aside the research on history of philosophy of science of the last twenty years Einführung ends up seriously distorting

3 A side remark on the bibliography of Einführung: A natural requirement for the bibliography of an introductory treatise is to mention the most accessible editions of the literature used. For some twenty years or so cheap and accessible German translations or editions of the works of Bachelard, Kuhn, Lakatos, Neurath, Popper, Schlick are available. Einführung mentions none of them. Instead, the German reader is advised to consult Pierre Wagner's anthology Les Philosophes et la Science. Wagner's anthology is certainly useful for French readers but is of limited use for German-speaking beginners. 
some of the essential features of the evolution of philosophy of science in the last century, or so I claim.

Let us consider a handful of examples of how key episodes and issues are treated in Einführung. As many authors before him, Moulines chooses Kant as the starting point of the prehistory of modern philosophy of science. In keeping with his general strategy described above none of them is mentioned in Einführung. I don't think that such a strategy can be justified in the case of Kant. As evidence we may take the role of Neokantianism. Moulines makes short shrift with the role of Neokantianism for the new emerging discipline of philosophy of science:

Man muß jedoch zugeben, daß der Neukantianismus kaum zur Bildung der spezifischen Thematik der modenen Wissenschaftstheorie beigetragen hat. (22)

This claim directly flies into the face of much solid work on history of philosophy of science that has been carried out in the last twenty years. Take, for instance, Coffa's trail-blazing monography From Kant to Carnap. To the Vienna Station (Coffa 1991). There, Coffa gave the following report on the relation between Neokantianism and "Viennese positivism":

All of the leaders of Viennese positivism began their philosophical path as neokantians, in particular Schlick. The particular brand of neo-kantianism [Schlick] endorsed had been inaugurated in the writings of Helmholtz and developed by other great scientists, including Planck. Indeed, Helmholtz himself considered his philosophy of science as sort of a scientifically improved Kantianism. (Coffa 1991, 171)

Coffa's From Kant to Carnap spawned a wealth of further studies investigating the role of (Neo)-kantianism in the evolution of modern philosophy of science. Here, $e$ pluribus unum, the work of Michael Friedman may be mentioned. As many studies Friedman's confirm that Moulines's verdict on the unimportance of Neokantian philosophy for philosophy of science is hardly tenable.

Chapter II of Einführung deals with the "preformative" phase at the end of the 19th and early 20th century when the new discipline unfolded. Its most interesting section examines the role of Ernst Mach for the fledgling philosophy of science. Today, Mach is a relatively unknown figure outside the circle of professional philosophers of science. Hence it is to be highly welcomed that he is treated in an introductory treatise. Einführung concentrates on Mach as one of the founding fathers of monism. According to Machian monism there are nothing but "sensations" which are the common elements of all possible physical and psychical experiences, which merely consist in the different kinds of ways in which these elements are combined, or in their dependence on one another. Mach's theory of "elements" (sensations) sought to connect physics, physiology and psychophysics and to provide a solid, non-metaphysical base for all of science. More generally, he conceived the language of "elements" and their relations as a medium usable for all the sciences. This Machian program of a unified science was not only theo- 
retically motivated, Mach characteristically conceived science as a part of a progressive enlightenment and gradual emelioration of human life. Although these "political" aspects of Mach's philosophy of science played an important role for his later influence, in particular on the Logical Empiricism of the Vienna Circle, they are hardly mentioned in Einführung.

Let us have now a look on the central chapter III - the phase of "unfolding” (40-59). It primarily deals with the contribution of the Vienna Circle and its branches to modern philosophy of science. Without any doubt, the Circle played a crucial role for the development of our discipline, and an introductory text should get it right. In Einführung one finds the following description of the Verein Ernst Mach for the logical empiricist philosophy of science:

... 1928 [wurde] unter [Schlicks] Vorsitz der Ernst-Mach-Verein (sic) gegründet, ein Zusammenschluss wissenschaftlich gebildeter Philosophen und Fachwissenschaftler mit philosophischen Interessen, die sich regelmäßig trafen, um alle Arten philosophischer Fragen in wissenschaftlichem Geist zu diskutieren. Weniger offiziell war die Gründung des Wiener Kreises ... durch die Mehrzahl der Mitglieder jener Vereinigung im Jahr 1929. (47)

In earlier writings the author even maintained that Schlick founded the Verein Ernst Mach and that this society, to be considered as the first institutionalized group of philosophers of science, gradually "changed into the Vienna Circle" (Moulines 2000, 486). Actually, things were quite different. The Verein was part of the Vienna system of adult education closely related to what can be succinctly described as the cultural and political network of Red Vienna. Originally the Verein was founded as Allgemeiner Naturwissenschaftlicher Bildungsverein Ernst Mach by the Österreichischer Freidenkerbund (Austrian Freethinkers' Association). According to the statutes, the aim of the Verein was

to promote the ideas and findings of natural science by offering courses, presenting lectures and papers, organizing guided tours and excursions and providing scientific literature. (Stadler 1997, 364)

The first official lecture in the Verein was given by Philipp Frank on "Travel Impressions of the Scientific World Conception in Russia”, later, his brother, the architect Josef Frank, gave a lecture on "The Modern World Conception and Modern Architecture", and the notorious Wilhelm Reich delivered a talk dealing with a topic of psychoanalysis (cf. Stadler 1982, 1997).

Characterizing the Verein Ernst-Mach as an institutionalized group of philosophers and scientists interested in academic discussions on issues of philosophy of science misses the point. It plays down the political aspects of the Viennese Logical Empiricism. The Vienna Circle appears as an academic and unpolitical discussion circle which renders the Circle's conception of philosophy of science rather similar to that propagated by the Münchner Schule some decades later. 
In Einführung only thin traces of the political dimension of the Vienna Circle's philosophy of science survive when, for instance, Neurath's account of philosophy of science is described as driven by strong "social-pedagogical motifs" (55). Rather cryptically, the author asserts that the positions of the Vienna Circle philosophers influenced "the Social-democratic program". Here are the plain facts: Neurath was a confessed although non-orthodox marxist, Hahn, Frank, Carnap and others characterized themselves as socialists (cf. Hegselmann 1979, Stadler 1997).

Today it is rather unanimously recognized that the Logical Empiricism of the Vienna Circle had strong ties to politically "progressive" currents in a quite similar vein as Machian positivism was almost universally understood to be liberal and progressive in its political implications. The shift to a socially disengaged, depolitized philosophy of science took place in the US in the 1950s. Ignoring this difference many philosophers and historians of philosophy tended to consider logical empiricism as an apolitical philosophical movement. As a result, after the Second World War Wissenschaftstheorie in Germany was generally associated with conservative or reactionary political currents. This held in particular for the Münchner Schule. Its founder Stegmüller was explicitly against any kind of "engaged" philosophy of science. When he was asked why he did not include a chapter on marxism in his Hauptströmungen der Gegenwartsphilosophie he replied that instead of "including a strange piece of contemporary theology he would rather prefer to include some honest piece of contemporary science.” Since then, a disengaged and depolitized conception has been a characteristic feature of the philosophy of science of the Münchner Schule. Moulines's (structuralist) philosophy of science faithfully follows the founder in this respect:

[S]tructuralism is a theory about science. But, of course, it is not a theory about every aspect of science. For example, it is not a theory about the ethical or political aspects of science, ... (Moulines 1996, 2)

Let us now have a closer look on how Einführung deals with some key themes of $20^{\text {th }}$ century philosophy of science. Einführung rightly emphasizes the importance the so-called protocol-sentence debate for the development of Logical Empiricism and for 20th-century philosophy of science as a whole (51f). In the last twenty years or so, some book-length treatises have been dedicated to this issue, see for instance Uebel's Overcoming Logical Positivism from within: the Emergence of Neurath's Naturalism from the Vienna Circle's Protocol-Sentence Debate (Uebel 1991). Of course, the subtleties of Uebel's detailed reconstruction have no place in a short introductory book like Einführung. But it would have been helpful for the beginner if some references to the secondary literature on the protocol-sentence debate had been given.

An analogous remark applies to the discussion of Carnap's The Logical Construction of the World (Aufbau) that Moulines offers in his book. In the last 
decades a profusion of different, in many aspects diverging interpretations of Carnap's opus magnum have been put forward. It goes without saying that they cannot be mentioned in a short introductory book. But the reader of Einführung may expect at least to find some references to the existing literature in the bibliography.

As a final example that a short paper ("Einzelstudie") may challenge some deeply ingrained opinions about the global structure of the historical development of philosophy of science let us mention George Reisch's article Did Kuhn Kill Logical Positivism? (Reisch 1991) that showed the accepted conventional wisdom concerning the relationship between Kuhn's historicist account of philosophy of science and logical empiricist philosophy of science was seriously oversimplified. Reisch pointed out that Carnap and other logical empiricists did not see Kuhn as an enemy. Rather, in a letter to Kuhn he confessed: "I very much like your ideas". This flexible attitude is in stark contrast with Stegmüller's claim that virtually all traditional (logical empiricist) philosophers of science considered Kuhn's historicism as a threat of philosophy of science.

In sum, Moulines's peculiar strategy in Einführung of not taking into account many results of the recent detailed research on history of philosophy of science makes his global picture of the development of the discipline problematic, to put it mildly.

Let us move now to a more general level. Philosophy of science, as well as philosophy in general, is beset with lots of "-isms". Every philosophical position has to explain where it is located with respect to the most important "-isms" of the field to which it belongs. So it seems expedient to describe the position of Einführung with respect to "-isms" that played a more or less important role for philosophy of science in the past century. Let us begin with relativism. In Einführung the author shows a deep-seated aversion to any kind of relativism. According to him, cultural relativists put forward absurd theses like the following one:

Die Aussage „Die Erde ist flach“ kann in unserer westlichen Kultur gut und gerne falsch sein; wenn eine Gruppe Ureinwohner in Neuguinea oder sonstwo glaubt, sie sei wahr, dann ist sie auch wahr, punktum. (122/123)

One need not be a partisan of philosophical relativism to feel a certain unease about this brusque way of dismissing this philosophical stance. After all, relativistic positions of various kinds have survived in philosophy since antiquity. According to Moulines, a source of the relativist evil in $20^{\text {th }}$ century philosophy has been Marxism:

Das marxistische Postulat, wonach die philosophischen oder sogar die wissenschaftlichen Ideen im wesentlichen von der sozialen Schicht abhängen, der die sie unterstützenden Individuen angehören, ist dabei eine stillschweigende, aber offensichtliche Quelle der Inspiration für den modernen Relativismus. (123) 
Not only Marxists will disagree with this blunt dismissal. Even for an introductory text one would ask for a more sophisticated discussion. Issues concerning relativist and Marxist positions in philosophy of science are a bit more complex than these harsh remarks suggest.

Pragmatism has a mixed appearance in Einführung. On the one hand, Peirce's philosophy of science is mentioned as one of two "seeds for the future" at the end of the preformative phase (the other "seed of the future" is formal logic) (38). Moulines succinctly formulates a simplified version of Peirce's famous "pragmatic maxim" (without mentioning this term). Surprisingly, there is no further reference to Peirce in the rest of the book and the bibliography. This makes it impossible for the unversed reader to figure out what the short remarks on the Peircean "seed" really amount to. This is a pity, since Peircean themes as the pragmatic maxim, the method of abduction, and the problem in what sense scientific knowledge may be conceptualized as converging to a "final theory", have been important issues on the agenda of the 20th century philosophy of science. Peirce's fellow pragmatist William James is dealt with in Einführung only as a partisan of monism (30f). Other pragmatists such as John Dewey, Clarence I. Lewis or Charles W. Morris are not mentioned at all. This is insofar surprising as in the midst of the 20th century pragmatism was the most important current in American philosophy. The protean figure of Putnam, who considers himself as a pragmatist in James's tradition, is not treated as such.

In line with the Anglo-Saxon meaning of "science", only the empirical sciences are the objects of philosophy of science (Wissenschaftstheorie), as the humanities (Geisteswissenschaften) or the social and cultural sciences are not considered. This may be considered as a bit odd insofar as the structuralist theory of science always proudly contended that it could handle all kinds of theories, irrespectively of whether they belonged to the realms of Naturwissenschaften or Geisteswissenschaften (cf. Balzer and Moulines 2000, Balzer 2009).

The restriction to the empirical sciences also excludes mathematics from the scope of that brand of philosophy of science that is treated in Einführung. According to Moulines, the philosophy of the empirical sciences and the philosophy of mathematics developed quite separately from each other (12). This move may help to keep things simple. But I am not so sure it can be justified. After all, already in his Intellectual Autobiography Carnap asserted that "the nature of logic and mathematics can be clearly understood only if close attention is given to their application in non-logical fields, especially empirical science” (Carnap 1963, 12). Similar theses may already be found in Frege and Cassirer. Thus for the phases of "preformation" and "unfolding" the relation between mathematics and empirical knowledge was a more important issue on the agenda of 20th century philosophy of science as Einführung would like us to believe.

Although Einführung contains a more or less implicit plea for structuralist theory of science, it is not, of course, a piece of structuralist philosophy of science proper. Rather, structuralism is presented as a member of a family of more or less 
similar approaches that all have their origins in the work of Patrick Suppes and his school (chapter VI). They all are characterized by the fact that the concept of a „model“ plays a central role for them. In Einführung they are subsumed under the rather ugly name Modellistische Ansätze (VI). The author rightly recognizes that it is hardly possible to describe the common features and the most salient differences between them in a succinct and clear-cut way. In any case, for Moulines the best among them is the so-called "metatheoretical structuralism" of Stegmüller and Sneed. It is distinguished from the other members of the family by the fact that it is the only current that takes into account some ideas from the historicist phase of philosophy of science, in particular from Kuhn. Thus it is said to offer a kind of dialectical synthesis of the preceding more or less one-sided phases of philosophy of science. This assessment is rather similar to the one Stegmüller put forward in A Combined Approach (1979) where he expressed the hope that the structuralist approach would provide a "bridge between the systematically, the historically, and the psychologically oriented philosophy of science" (ibid., 181). After thirty years have passed there is not much evidence that Stegmüller's hope was more than a pious dream.

To be sure, Einführung is not a piece of structuralist philosophy of science proper. We are shown the promised land of structuralist philosophy of science from a distance, so to speak, but, like Moses, we do not enter into the structuralist paradise. What structuralist philosophy of science really amounts to, the reader may learn from the compilation Structuralist Knowledge Representation. Paradigmatic Examples (Balzer, Sneed and Moulines 2000), or, on a more elementary level, by Balzer's "textbook of structuralist philosophy of science" Die Wissenschaft und ihre Methoden. Grundsätze der Wissenschaftstheorie, Ein Lehrbuch (Balzer 2009).

In these works the pretension of structuralism to be the leading account of contemporary philosophy of science is expressed quite explicitly. For instance, in the preface of Structuralist Knowledge Representation the editors contend that the structuralist notation is the best notation for the representation of scientific knowledge available. For this claim they offer an argument that shows up in Einführung again:

Our ... argument ... is that our representation format has passed the test of general applicability. In the literature, one can find now more than 40 reconstructions and case studies from various disciplines all using the structuralist format ... looking at the examples ranging from purely qualitative theories like Freud's theory of the unconsciousness to highly mathematized physical theories in general relativity theory the claim that all scientific theories can be cast into our frame does not seem to be a bold one.” (Balzer and Moulines 2000, 9).

As a co-compiler of the Bibliography of Structuralism (Diederich, Ibarra, Mormann 1989, 1994) I feel competent to give a more realistic estimation. Since the number of reconstructed theories does not diminish, the herbarium of structuralistically reconstructed theories today comprises at least 100 specimens. 
In other words, scarcity of structuralist reconstructions is certainly not the problem. Rather, a major problem of structuralist philosophy of science is to give a convincing answer to the question "What are all these reconstructions good for?" Most simply serve as trophies evidencing the versatility of the structuralist approach. The great majority of philosophers simply ignores them, as well as the practitioners of the reconstructed scientific theories.

Structuralist reconstructions evoke the idea of glass bead games whose apparent precision cannot hide the fact that they have not much to do with real scientific knowledge. Of course, in Einführung matters are assessed in a different way. Rehearsing the just mentioned argument of Balzer and Moulines (2000), the author of Einführung considers it one of the great merits of structuralism to have "described at least fifty theories from all scientific disciplines ... in all their comprehensiveness and with highest precision” (162). Frankly, I have some qualms with this alleged "highest precision". If we conceive structuralist reconstructions (like Carnap's constitutional systems) as maps of scientific knowledge (cf. Goodman 1963 and Kitcher 2001) the mapmaker may contend that his maps meet the highest standards of precision whatsoever, the only relevant question being whether his maps are serviceable for the purposes of their users. But who uses the structuralist maps? I don't think that it is sufficient to answer this question with the remark that the philosophy of science is an autoreferential system whose products are produced only for its own needs. If this were the case, philosophy of science would be doomed to intellectual irrelevance. I think, a global account of philosophy of science should be concerned with articulating a "model" of science that brings into clearer focus the global questions concerning science, among them the question about the role of science in our society and culture.

Time to take stock. In my opinion, Einführung does not give a satisfying account of the history of philosophy of science. What it does is to offer a concise presentation of the view of the Münchner Schule on the evolution of philosophy of science. This view essentially boils down to the conception that Stegmüller formulated some thirty years ago including some new figures that entered the stage after Stegmüller. With Einführung we are back in the Golden Age of the Münchner Schule of the 1970s and 1980s when its members began to bless the philosophical community with structuralist reconstructions of all kinds of theories. The guiding idea of the dialectics underlying Einführung, namely, that structuralism, as the culmination of philosophy of science, is the only account that successfully synthesized diachronic and synchronic perspectives on science, can already be found in Stegmüller's Combined Approach.

In a similar vein as the founder of the Münchner Schule Einführung subscribes to a perspective on science, from which many interesting and important aspects of this multi-facetted object get invisible. In the Munich perspective, science is an autonomous, purely epistemic enterprise. Correspondingly, philosophy of science is a purely "metatheoretical" endeavour. This is, of course, a possible proposal of how to conceive philosophy of science. But today quite a few philosophers of 
science have come to doubt that this proposal offers a promising prospect for "a philosophy of science for the twenty-first century” (cf. Kouranyi 2003).

\section{BIBLIOGRAPHY}

Balzer, W., 2009, Die Wissenschaft und ihre Methoden. Grundsätze der Wissenschaftstheorie. Ein Lehrbuch, Freiburg, München, Alber. Zweite Auflage.

Balzer, W., Moulines, C. U., 2000, Introduction, in W. Balzer, J. D. Sneed and C. U. Moulines (eds.), Structuralist Knowledge Representation. Paradigmatic Examples, Poznan Studies in the Philosophy of Science and the Humanities 75, 5-18.

Dahms, H.-J., 1985, Philosophie, Wissenschaft, Aufklärung (Hrsg.), Berlin und New York, de Gruyter.

Dahms, H.-J., 2010, Strukturalismus, in F. Stadler (Hrg.), Vertreibung, Transformation und Rückkehr der Wissenschaftstheorie. Am Beispiel von Rudolf Carnap und Wolfgang Stegmüller, LIT Verlag, Berlin.

Diederich, W., Ibarra, A., Mormann, T., 1989, Bibliography of Structuralism, Erkenntnis 30 (3), 387-407.

Diederich, W., Ibarra, A., Mormann, T., 1994, Bibliography of Structuralism II (1989-1994 and Additions), Erkenntnis 41 (3), 403-418.

Giere, R., Richardson, A. W., 2003, Origins of Logical Empiricism (eds.), Minnesota Studies in the Philosophy of Science XVI, Minneapolis, University of Minnesota Press.

Goodman, N., 1963, The Significance of Der logische Aufbau der Welt, in P. A. Schilpp (ed.) The Philosophy of Rudolf Carnap, Chicago and LaSalle, Open Court, 545-558.

Haller, R., 1993, Historische Einführung in den Logischen Positivismus, Darmstadt, Wissenschaftliche Buchgesellschaft.

Hardcastle, G., Richardson, A. W., 2003, Logical Empiricism in North America (eds.), Minnesota Studies in the Philosophy of Science XVIII, Minneapolis, University of Minnesota Press.

Howard, D., 2003, Two Left Turns Make a Right: On the Curious Political Career of North American Philosophy of Science at Midcentury, in G. Hardcastle and A. W. Richardson (eds.), 25-93.

Kitcher, P., 2001, Science, Truth, and Democracy, Oxford, Oxford University Press.

Kouranyi, J. A., 2003, A Philosophy of Science for the Twenty-first Century, Philosophy of Science 70, 1-14.

Moulines, C. U., 2000, Balance y perspectivas de la filosofía de la ciencia, Éndoxa 12, 485-494. UNED, Madrid. 
Moulines, C. U., 2008, Die Entstehung der Wissenschaftstheorie als interdisziplinäres Fach (1885-1914), Bayerische Akademie der Wissenschaften, Philosophisch-Historische Klasse, Sitzungsberichte, Jahrgang 2008, Heft 2., München, Verlag der Bayerischen Akademie der Wissenschaften in Kommission beim Verlag C. H. Beck.

Neurath, O., 1979, Wissenschaftliche Weltauffassung, Sozialismus, Logischer Empirismus, eingeleitet und herausgegeben von R. Hegselmann, Frankfurt/ Main, Suhrkamp Verlag.

Reisch, G. A., 1991, Did Kuhn Kill Logical Empiricism?, Philosophy of Science 58, 264-277.

Reisch, G. A., 2005, How the Cold War Transformed Philosophy of Science. To the Icy Slopes of Logic, Cambridge, Cambridge University Press.

Stadler, F., 1982, Vom Positivismus zur „Wissenschaftlichen Weltauffassung “. Am Beispiel der Wirkungsgeschichte von Ernst Mach in Österreich von 18951934, Wien und München, Löcker.

Stadler, F., 1997, Studien zum Wiener Kreis. Ursprung, Entwicklung und Wirkung des Logischen Empirismus im Kontext, Frankfurt/Main, Suhrkamp.

Stadler, F., 2010, Vertreibung, Transformation und Rückkehr der Wissenschaftstheorie. Am Beispiel von Rudolf Carnap und Wolfgang Stegmüller (Hg.), Wien, Berlin, LIT Verlag.

Stegmüller, W., 1979, The Structuralist View of Theories. A Possible Analogue of the Bourbaki Programme in Physical Science, Berlin-Heidelberg-New York, Springer.

Stegmüller, W., 1979, A combined approach to the dynamics of theories. How to improve historical intepretations of theory change by applying set theoretical structures, in The Structure and Development of Science, G. Radnitzky and G. Anderson (eds.), Reidel, Dordrecht.

Uebel, T., 1992, Overcoming Logical Positivism from Within. The Emergence of Neurath's Naturalism in the Vienna Circle's Protocol Sentence Debate, Amsterdam and Atlanta, Rodopi.

Uebel, T., 2010, Some Remarks on Current History of Analytical Philosophy of Science, in F. Stadler (ed.) together with D. Dieks, W. J. González, S. Hartmann, T. Uebel, M. Weber, The Present Situation in the Philosophy of Science, Dordrecht, Springer, 14-27.

Department of Logic and Philosophy of Science University of the Basque Country (UPV/EHU)

P.O. Box 1249

20080 Donostia-San Sebastián

Spain

ylxmomot@sf.ehu.es 